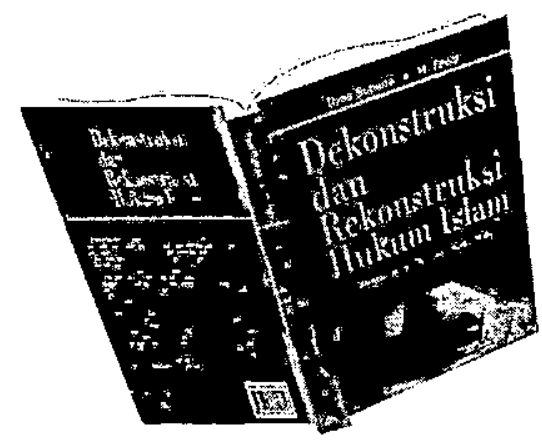

Judul buku

Penulis

Penerbit

Tebal buku

Cetakan/tahun
: Dekonstruksi dan Rekonstruksi Hukum Islam

: llyas Supena dan M. Fauzi

: Gama Media

: xvi + 301 halaman

: Pertama/ tahun 2002

\title{
Membongkar dan Menata Ulang Kejumudan Hukum Islam
}

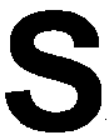
alah satu keunggulan Hukum Islam adalah elastisitas dan keuniversalannya. Hukum Islam selalu sejalan dengan pergantian ruang dan perjalanan waktu, dan mampu survive memenuhi kebutuhan umat Islam dan menjawab tantangan zaman sepanjang masa. Ketika Rosulullah masih hidup hukum Islam selalu menjadi pelopor untuk menjawab segala tantangan dan mampu memberi solusi setiap masalah yang muncul dipermukaan, baik yang berkenaan dengan masalah ibadah maupun yang berkenaan dengan masalah muamalah. Setelah Rosulullah meninggal dan kepemimpinan diteruskan oleh Khulafa'urrosyidin muncullah perbedaan pendapat dikalangan Ulama' dalam mensikapi masalah yang muncul di permukaan walaupun bisa dikompromikan.

Secara sunnatullah waktu terus berjalan dan pemimpin Islampun silih berganti. Permasalahan yang muncul juga berkembang dengan pesat, sementara pedoman untuk menyelesaikannya tetap Al-Qur'an dan Al-Sunnah, apabila masalah yang muncul tidak bisa diselesaikan dengan Qur'an dan Hadits, maka ditempuh dengan jalan litihad.

Al-Qur'an dan Al-Sunnah merupakan dua sumber utama dalam pemikiran Hukum Islam. Apabila di dalam Al-Qur'an ditemukan ketentuan hukum yang jelas, maka hukum itulah yang harus diambil, namun bila tidak ditemukan di dalamnya, maka dicari dalam al-Sunnah, jika di dalam keduanya tidak terdapat ketentuan hukum atau hanya disinggung secara samar, maka pencarian hukumnya 'melalui ijtihad atau ra'yi. (hal.167):

Pemakaian ketiga sumber tersebut harus diaplikasikan secara urut, artinya selama di dalam al-Qur'an telah ditemukan rumusan hukum yang jelas, maka tidak diperbolehkan mencarinya baik di dalam alSunnah maupun dengan cara ijtihad. Demikian juga bila al-sunnah telah menunjuk pada ketentuan hukum yang jelas, pemakaian ijtihad tidaklah diperbolehkan. (hal. 127). Jadi ijtihad merupakan alternatif terakhir metode penggalian hukum, apabila al-Qur'an dan al-sunnah sama sekali tidak 
menyebut ketentuan hukumnya, dan atau hanya menyinggungnya secara samar. Pemikiran ini didasarkan atas hadits tentang pengangkatan Mu'adz bin Jabal menjadi Qodli (Hakim) di kota Yaman, sebagai berikut: "Sesungguhnya Rosulullah saw ketika hendak mengutus Muadz ke Negeri Yaman berkata kepadanya: Bagaimanakah cara kamu menyelesaikan perkara yang diajukan kepadamu? Muadz menjawab, akan aku putuskan menurut ketentuan hukum yang ada dalam al-Qur'an. Rosul kemudian bertanya, kalau di dalam alQur'an kamu tidak mendapatkan , akan aku putuskan menurut hukum yang ada pada sunnah Rosul. Rosul bertanya lagi, kalau tidak juga kamu temukan baik dalam sunnah Rosul maupun dalam kitab Allah? Muadz menjawab: aku akan berijtihad dengan seksama. Setelah itu Rosul mengakhiri dialognya sambil menepuk-nepuk dada Muadz seraya berkata: segala puji hanya untuk Allah yang telah memberikan petunjuk kepada utusan RosulNya jalan yang diridloi Rosulullah". (HR. Abu Dawud).

: Praktek ijtihad telah dimulai sejak Rosulullah masih hidup, baik oleh Rosul sendiri maupun para sahabatnya. Pada umumnya ijtihad yang dilakukan Rosulullah adalah ketika terjadi suatu peristiwa, dan wahyu belum turun, hasil ijtihad itu ada kalanya dibenarkan al-Qur'an dan ada juga yang disalahkan Sedangkan ijtihad yang dilakukan para sahabatnya semasa hidup Rosul adalah, dengan cara memahami dan menafsirkan ayat al-Qur'an dan atau petunjuk Rosul yang masih interpretable (hal. 170). Pada masa generasi awal Islam ïtihad telah dipraktekkan tanpa ada teori dan aturan formal yang mengikatnya. Setelah Rosul wafat bentuk ijtihad dikembangkan dan dimodifikasi oleh para sahabat, dan diteruskan oleh Tabi'ien dan generasi berikutnya. Pengembangan tersebut dilakukan sebagai tuntutan realitas zaman, setelah Islam berkenalan dan bersentuhan dengan kebudayaan dan peradaban asing (h. 170).

Buku ini terdiri dari $10 \mathrm{bab}$, dan di dalamnya dibagi menjadi dua bagian. Bagian pertama tentang Dekonstruksi Hukum Islam, terdiri dari lima bab. Bgian kedua tentang Rekonstruksi Hukum Islam, terdiri lima bab pula, yang memuat sejak dari latar belakang pemikiran para ahli, metodologi pemikiran, formulasi epistemologi, dekostruksi hukum Islam sampai dengan memperbaiki kembali hukum Islam yang telah didekostruksi dengan menggunakan metodologi yang benar sesuai tuntutan zaman. Buku tersebut secara universal menyoroti adanya kejumudan perkembangan hukum Islam, dari analisis dan temuan yang dihasilkan adalah bahwa untuk mendobrak stagnasi berfikir ini setidaknya diperlukan adanya langkah yang cukup radikal, yakni hukum Islam yang harus dibongkar (didekonstruksi) untuk selanjutnya diperbaiki kembali (direkonstruksi). Gerakan bongkar pasang ini dilakukan tidak semata-mata untuk mengakselerasikan hukủm Islam yang seringkali dituduh rigid (kaku) dan tidak antisipatif terhadap perkembangan zaman. Lebih dari itu bahwa terjadinya kegagapan hukum Islam dalam mengikuti irama perkembangan zaman ini dikarenakan adanya kekeliruan metodologis. Hal ini sebagaimana yang telah diungkapkan penulis yang memulai tulisannya dengan ide pembongkaran hukum Islam kaitannya pada persoalan epistemologi. Menuru llyas persoalan epistemologi dalam kaitannya sebuah disiplin ilmu merupakan persoalan yang sangat krusial dalam menentukan format disiplin ilmu tersebut, termasuk didalamnya hukum Islam. Epistemologi akan sangat menentukan format disiplin ilmu tersebut terhadap hakekat, sumber dan 
faliditas ilmu pengetahuan yang pada gilirannya menentukan cara pandang orang yang menganut sistem epistemologi dalam disiplin ilmu tersebut terhadap lingkungan dan dunia sekitarnya. Berkaitan dengan hal tersebut penulis menyatakan bahwa sangatlah penting untuk membongkar epistemologi hukum Islam yang menyelimuti umat Islam sejak episteme abad klasik hingga abad modern sekarang ini, di mana problem yang dihadapi umat Islam sekarang ini jauh lebih complicated. Dengan strategi dekonstruksi ini Arkaun misalnya, seorang pemikir kelahiran Al-Jazair ingin membuka tabir yang membungkus kelahiran epistemeepisteme tersebut dengan membaca ulang ('adah al-qiraah/re-reading) (hal. 117) atas teks-teks yang melahirkan formulasi epistemologi hukum Islam, seperti contoh al-Risalah karya al-Syafi'ie. Dengan cara demikian diharapkan umat Islam dapat membedakan antara Islam yang normatif dan historis, atau dalam istilah Mohammad Arkoun antara kebenaran sosiologis (alhaqiqah al-susiulugiyyah) dan kebenaran hakiki (al-haqiqah al-haqiqiyyah) (hal. 149). Sehingga fenomena sakralisasi pemikiran (taqdis al-afkar), dan secara khusus fenomena "taqlidisme" dan bermazhab ansich yang mewarnai dalam kehidupan umat Islam, akan dapat diminimalisir. Inilah gagasan pertama yang coba dipotret dalam buku ini.

Gagasan ke dua merupakan tindak lanjut pasca dibongkarnya hukum Islam, yakni dengan merekonstruksinya. Gagasan yang ditulis oleh Fauzi ini memberikan salah satu jawaban yang selama ini dipertanyakan, yakni pembaharuan limitasi dan ruang lingkup ijtihad. Menurut Fauzi lebih lanjut dinyatakan bahwa ijtihad sebagai media dinamisási hukum Islam, pada masa generasi awal sangat progresif, bebas tanpa adanya aturan formal yang mengikutinya.
Namun dalam perkembangan ulama ushul fiqih membuat aturan-aturan yang diantaranya berupa pembatasan (limitation) Ruang lingkup dan syarat-syarat ijtihad. Para Ulama' ushul selanjutnya membuat pemilihan antara hukum-hukum yang menjadi wilayah ijtihad dan tidak menjadi wilayah ijtihad. Secara garis besar wilayah ijtihad ini meliputi dua hal. Pertama hukumhukum yang tidak ada petunjuk nasnya sama sekali. Kedua hukum-hukum yang ditunjuk oleh nash dzonni. Sedangkan hukum-hukum yang telah ditunjuk dengan qot'ie dalalah tak ada sedikitpun peluang bagi ijtihad.

Menurut Fauzi, Imam Al- Syafi'ie sebagai the founding fathers ushul figh, sedikit banyak telah mewarnai pemikiran ushuliyyin generasi berikutnya. Salah satu ide side effect pengaruh Imam al-Syafi'ie adalah muncuinya limitasi syarat-syarat ijtihad.

Aturan yang dicetuskan oleh Imam alSyafi'i ini mengharuskan adanya kemampuan keilmuan yang harus dimiliki seorang yang akan melakukan Qiyas, yang diidentikkan dengan ijtihad. Disamping itu doktrin teologi ternyata ikut ambil bagian dalam mempengaruhi pembatasan ruang lingkup ijtihad yang dibuat oleh Ushuliyyin. Pengaruh tersebut terefleksi dalam definisi ijtihad yang diberikan oleh Ushuliyyin. Dari definisi tersebut misalnya, bahwa ijtihad tidak boleh menyentuh pada hal yang qoth'iy (hal. 225). Diantara term-term tersebut adalah: Al-hukmu al-syari' atau al-ahkam alsyari', dan dzat yang dimaksudkan adalah untuk mengeluarkan masalah-masalah aqliyat, kalam, hukum-hukum qath'iy dan ruang lingkup garapan ijtihad.

Rumusan definisi yang sudah mengarah pada pemilihan lapangan ijtihad, diperjelas lagi ketika ushuliyyin membahas 
masalah mujtahid fihi (ruang lingkup ijtihad). Dalam hal ini masalah-masalah yang dikecualikan tersebut (aqliyat, kalam, dan hukum qath'iy) secara tegas dinyatakan tidak boleh disentuh untuk dijithadi (untouchable ijtihad). Hal ini menunjukkan adanya pengaruh teologi, khususnya sunni yang lebih cenderung menginginkan persamaan persepsi dalam masalahmasalah tersebut.

Pengaruh limitasi dari doktrin teologi ini juga nampak dalam pembahasan masalahmasalah taswibah wa takhti'ah (benar atau salahnya ijtihad). Dalam konteks ini Ushuliyyin sepakat bahwa dalam bidang termasuk Qot'iyyah kebenaran hanya satu, dan Mujtahid yang benar hanya satu, sedangkan yang bersalah akan berdosa. Pembahasan konsep ini jelas mempengaruhi gerak dinamika ijtihad, dengan tidak memperbolehkan ijtihad pada wilayah qothiy dimana kalam dan aqidah masuk didalamnya. Sedangkan untuk pengaruh doktrin teologi terhadap syarat-syarat ijtihad, tercermin dalam kekhawatiran akan terjadinya kefakuman mujtahid, dan mengakui kepunahannya pasca Imam Madzhab. Keyakinan ini didasarkan atas alasan sudah dekatnya kiamat yang ditandai dengan lahirnya orang-orang tidak cerdas.

Diakui atau tidak pembuatan limitasi ijtihad tersebut ternyata membawa dampak terhadap perkembangan pemikiran hukum Islam. Dibatasinya ïtihad dengan tidak boleh menyentuh nas qath'iy dalalah telah menyebabkan pembaharuan hukum Islam yang bersifat parsial ad hoc. (hal. 290). Karena untuk mewujudkan pembaharuan secara universal dalam buku ini ditawarkan adanya pemberian ruang gerak ijtihad seluas-Iuasnya, termasuk yang Qath'iy dalalah sekalipun. Sehingga sebagai akibatnya rumusan-rumusan syarat-syarat ijtihad harus fleksibel elastis dinamis sesuai dengan kebutuhan mujtahid. Terlebih dalam era sekarang ini yang memungkinkan orang bisa saling kerjasama dalam berijtihad.

Dua gagasan ini memang sengaja untuk digabungkan menjadi satu tema, dan sebagai karya yang diambil dari hasil thesis dapat disebut langka dan unik, yakni keberaniannya untuk membongkar tradisi pemikiran yang telah termapankan dengan menggantikannya pada paradigma yang serba baru, yakni cara merujuk hukum Islam pada epistemologi baru yang telah terpetakan makna wilayah Islam historis dan normatif, serta terbebaskannya mujtahid pada syarat-syarat ijtihad yang terlalu ketat dan limitatif.

Buku ini bermanfaat untuk dibaca, dan untuk dijadikan pegangan bagi mahasiswa, dosen, pembaharu dan calon pembaharu hukum Islam, sebagai salah satu rujukan untuk menentukan secara tepat paradigma berfikir logis dan universal.

Ibnu Hadjar. 